\title{
TIẾP CẬN NÔN TRỚ Ở TRẺ SƠ SINH
}

\author{
Nguyễn Thị Lam Hồng, Vương Thị Huyền Trang, Vũ Thị Tâm \\ Khoa HSCC Sơ sinh, Bệnh viện Nhi Trung ương
}

\section{1. Đ!̣H NGHĨA}

Nôn là một triệu chứng tiêu hóa phổ biến của trẻ sơ sinh có thể gặp trong nhiều bệnh lý liên quan đến nhiều cơ quan khác nhau.

Nôn được định nghĩa là tình trạng các chất trong dạ dày bị đẩy ra ngoài qua miệng, do sự co bóp của dạ dày phối hợp với co thắt của các cơ thành bụng và ngực.

Trớ là sự di chuyển của chất trào ngược từ dạ dày qua hầu họng lên miệng, hoặc có thể qua miệng ra ngoài số lượng ít, do sự co bóp đơn thuần của dạ dày. Trớ là một triệu chứng rất hay gặp ở trẻ sơ sinh, so với nôn, trớ thường không mạnh, số lượng dịch thường nhỏ $<5-10 \mathrm{ml}$, thường xuất hiện sau ăn, khi trẻ ợ hơi. Nguyên nhân thường do ăn nhanh hoặc ăn quá mức và nuốt nhiều khí và chỉ cần vỗ nhẹ lên lưng trẻ là có thể giúp giải quyết vấn đề này.

\section{SINH LÝ HỌC}

Nôn khởi phát bằng việc tăng nhu động dạ dày - ruột, bắt đầu bằng việc nôn không tự chủ. Sự co bóp đồng thời của cơ hoành, cơ liên sườn và cơ bụng là tăng áp lực trong ổ bụng, kết hợp với sự giãn của cơ thắt thực quản dưới dẫn đến kết quả là thức ăn trong dạ dày bắt buộc phải tống ra ngoài.

\section{KHÁM LÂM SÀNG}

Đối với một trẻ có vấn đề nôn, việc đầu tiên là cần khai thác đầy đủ về tiền sử, đặc biệt các tiền sử liên quan đến chế độ dinh dưỡng của trẻ.

- Khởi phát khi nào

- Số lượng

Nhận bài: 10-2-2021; Chấp nhận: 15-4-2021

Người chịu trách nhiệm chính: Nguyễn Thị Lam Hồng

Địachi:lamhong1313@yahoo.com
- Nôn vọt hay thụ động

- Màu sắc? Sữa? Xanh?

- Có liên quan đến bữa ăn?

- Tần suất bữa ăn

- Trẻ đã ỉa phân su?

- Bụng chướng

- Tiền sử sản khoa: đa ối, thiểu ối?

- Sàng lọc trong bào thai, vôi hóa

- Hình thức nuôi ăn sau sinh, tần suất, số lượng, trẻ có ợ không?

- Khám lâm sàng là vô cùng quan trọng trong đánh giá một trẻ sơ sinh có vấn đề nôn trớ.

- Toàn trạng: cân nặng và chiều cao có tương ứng với độ tuổi của trẻ không?

- Quan sát triệu chứng nôn: nôn vọt, nôn khan hay nôn ra sữa (sữa mới trắng hay sữa vón), màu sắc chất nôn (vàng, xanh hay gợn nâu?).

- Hoàn cảnh xuất hiện nôn: Nôn vào thời điểm nào trong ngày, có liên quan đến bữa ăn không.

- Quan sát màu sắc da, niêm mạc, nhịp thở, nhiệt độ, dấu hiệu mất nước và tinh thần của trẻ khi nôn và ngoài lúc nôn.

- Các biểu hiện nhiễm trùng của hệ hô hấp: chảy mũi, ngạt mũi, ho, đờm?

- Các biểu hiện của đường tiêu hóa: chậm nhu động ruột, táo bón, tiêu chảy, đây hơi?

- Các biểu hiện thần kinh: trẻ quấy khóc, thóp phồng, hốt hoảng, co giật.

- Các triệu chứng lâm sàng ở trẻ sơ sinh đôi khi không rõ ràng và điển hình, có thể rất khó khăn cho chẩn đoán. Tuy nhiên có một số dấu hiệu lâm sàng cần được lưu ý kỹ và cảnh báo. 
TẠP CHÍ NHI KHOA 2021, 14, 2

- Nôn ra máu (đỏ hoặc đen)

- Nôn dịch mật (xanh, không phải vàng)

- Nôn vọt

- Trẻ không khỏe

- Trẻ chậm tăng trưởng

- Trẻ có luồng trào ngược
- Nôn và tiêu chảy

- Bụng chướng

\section{CÁC NGUYÊN NHÂN THƯờNG GĂP}

\subsection{Nguyên nhân nôn theo hệ thống}

Triệu chứng nôn thường gặp nhất trên những trẻ có bệnh lý về đường tiêu hóa, và chia theo nguyên nhân khác nhau.

\begin{tabular}{|l|l|}
\hline Nhiễm trùng & $\begin{array}{l}\text { Rối loạn nhu động } \\
\text { Co thắt thực quản }\end{array}$ \\
$\begin{array}{l}\text { Viêm dạ dày ruột } \\
\text { Viêm phúc mạc } \\
\text { Viêm ruột thừa } \\
\text { Viêm gan }\end{array}$ & $\begin{array}{l}\text { Giãn đại tràng bẩm sinh } \\
\text { Liệt dạ dày }\end{array}$ \\
\hline Tắc nghẽn cơ học & Viêm \\
Bất thường bẩm sinh & Trào ngược dạ dày thực quản \\
Bất thường quay ruột + xoắn ruột & Viêm dạ dày \\
Lồng ruột & Loét tá tràng \\
Tắc ruột phân su & Viêm tụy \\
Thoát vị nghẹt & Dị ứng/không dung nạp thức ăn \\
\hline
\end{tabular}

Các nguyên nhân phân loại theo hệ thống viêm tai giữa, nhiễm trùng máu. khác có thể gặp là:

- Thần kinh: Tăng áp lực nội sọ, não úng thủy, u não, thuốc (hóa trị liệu).

- Nhiễm trùng viêm màng não, viêm phổi,

- Chuyển hóa chu trình ure, galactosemia

- Nội tiết tăng sản thượng thận bẩm sinh

- Nhiễm độc rượu, aspirin.

- Thận tắc nghẽn, suy thận, toan ống thận.

\subsection{Nguyên nhân thường gặp theo lứa tuổi}

\begin{tabular}{|l|l|l|}
\hline \multicolumn{1}{|c|}{ Sơ sinh } & \multicolumn{1}{|c|}{ Trẻ em } & \multicolumn{1}{c|}{ Người lớn } \\
\hline Viêm dạ dày ruột & Viêm dạ dày ruột & Viêm dạ dày ruột \\
Trào ngược dạ dày thực quản & Viêm dạ dày & Trào ngược dạ dày thực quản \\
Ăn quá mức & Ngộ độc thức ăn & Viêm dạ dày \\
Tắc nghẽn giải phẫu & Trào ngược (GERD) & Viêm ruột kích thích \\
Nhiễm trùng hệ thống & Thuốc & Viêm ruột thừa \\
Viêm tai giữa & Nhiễm trùng hệ thống & Ngộ độc thức ăn \\
& Viêm xoang & Nhiễm trùng \\
& Viêm tai giữa & Viêm xoang \\
& & Đau nưa đầu \\
& & Mang thai \\
& & Thuốc \\
\hline
\end{tabular}




\subsection{Nguyên nhân hiếm gặp}

\begin{tabular}{|c|c|c|}
\hline So sinh & Trẻ em & Người lớn \\
\hline $\begin{array}{l}\text { Tăng sản thượng thận bẩm sinh. } \\
\text { Rối loạn chuyển hóa } \\
\text { U não (tăng áp lực nội sọ) } \\
\text { Chảy máu dưới màng cứng } \\
\text { Ngộ độc thức ăn } \\
\text { Toan ống thận }\end{array}$ & $\begin{array}{l}\text { Hội chứng Reye } \\
\text { Viêm gan } \\
\text { Loét đường tiêu hóa } \\
\text { Viêm tụy } \\
\text { U não } \\
\text { Tăng áp lực nội sọ } \\
\text { Viêm tai giữa } \\
\text { Hóa trị liệu } \\
\text { Nôn chu kỳ (đau nửa đầu) } \\
\text { Hẹp thực quản } \\
\text { U máu tá tràng } \\
\text { Rối loạn chuyển hóa }\end{array}$ & $\begin{array}{l}\text { Hội chứng Reye } \\
\text { Viêm gan } \\
\text { Loét đường tiêu hóa } \\
\text { Viêm tụy } \\
\text { U não } \\
\text { Tăng áp lực nội sọ } \\
\text { Viêm tai giữa } \\
\text { Hóa trị liệu } \\
\text { Nôn chu kỳ (đau nửa đầu) } \\
\text { Bệnh lý đường mật } \\
\text { Bệnh lý thận }\end{array}$ \\
\hline
\end{tabular}

\section{PHÂN LOẠI - CHẨN ĐOÁN MỘT SỐ NGUYÊN NHÂN THƯờNG GẶP}

Có nhiều cách phân loại khác nhau, để tiếp cận đơn giản người ta thường phân chia làm 2 loại: nôn dịch mật và nôn không dịch mật. Việc xử trí 2 loại là rất khác nhau, đặc biệt đối với nôn dịch mật ở trẻ sơ sinh luôn luôn là một cấp cứu ngoại khoa cho đến khi chẩn đoán loại trừ.

\subsection{Nôn dịch mật}

Nguyên nhân của nôn dịch mật

Nguyên nhân tắc nghẽn

- Bất thường quay ruột

- Xoắn ruột

- Tắc ruột

- Teo ruột

- Tắc ruột phân su

- Giãn đại tràng bẩm sinh

- Không hậu môn

- Thoát vị nghẹt

Rối loạn của dạ dày - ruột

- Viêm ruột hoại tử

- Liệt ruột
- Viêm phúc mạc

- Dị ứng sữa

- Giảm nhu động không tắc nghẽn

Các nguyên nhân nôn dịch mật ít gặp khác

- Nhiễm trùng: Nhiễm trùng huyết, viêm màng não.

- Rối loạn thần kinh: Vàng da nhân, chảy máu dưới màng cứng, phù não, não úng thủy.

- Rối loạn nội tiết và chuyển hóa: chu trình ure, galactosemia, tăng sản thượng thận bẩm sinh, co cứng cơ ở trẻ sơ sinh.

- Bệnh lý thận tắc nghẽn đường tiểu, suy thận.

- Tuy nhiên, các nguyên nhân ngoại khoa thường gặp và cần phải xử trí cấp cứu, trong đó có một số nguyên nhân phổ biến.

\subsubsection{Tắc tá tràng}

- Tắc tá tràng là tắc nghẽn bẩm sinh của đoạn hai tá tràng.

- Thường liên quan đến đa ối trong thời kỳ mang thai.

- Tỷ lệ $1 / 5000$ đến $1 / 10000$ trẻ sống

- $25 \%$ đi kèm với hội chứng Down, $20 \%$ có bệnh lý tim bẩm sinh. 


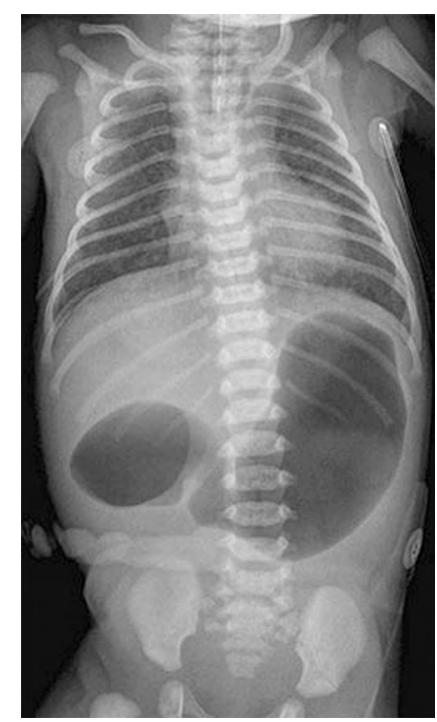

\subsubsection{Bất thường quay ruột và xoắn ruột}

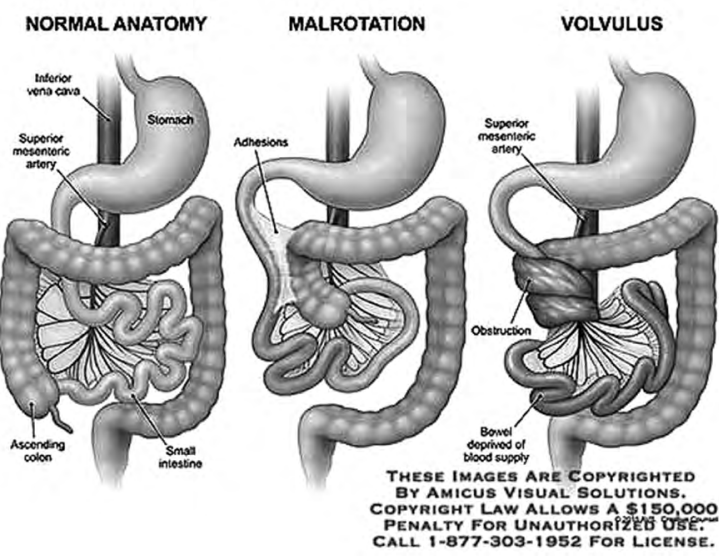

- Hầu hết bệnh nhân bị bất thường quay ruột sẽ phát triển với xoắn ruột trong tuần đầu tiên của cuộc đời.

- Nôn dịch mật là triệu chứng ban đầu nhưng sự chướng bụng không đáng kể.

- Siêu âm với Doppler màu cho thấy dấu hiệu "xoáy nước".

\subsubsection{Teo hỗng tràng}

Nguyên nhân bởi sự bất thường mạch máu mạc treo ruột trong thời kỳ bào thai.

\section{Bốn type}

1. Màng ngăn

2. Dây xơ

3. Gián đoạn

\section{Teo nhiều chỗ}

- Bụng chướng với nôn dịch mật xuất hiện trong 24 giờ đầu sau sinh.

- Phim chụp bụng thẳng đứng cho thấy các quai ruột giãn to với nhiều mức nước - hơi gợi ý hình ảnh tắc ruột thấp.
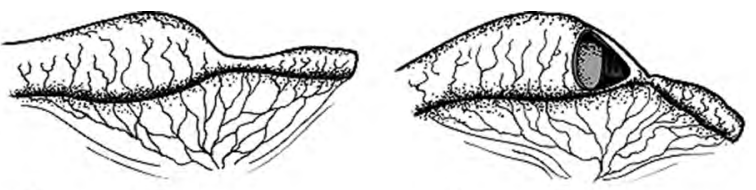

(A)

Stenosis

Type I
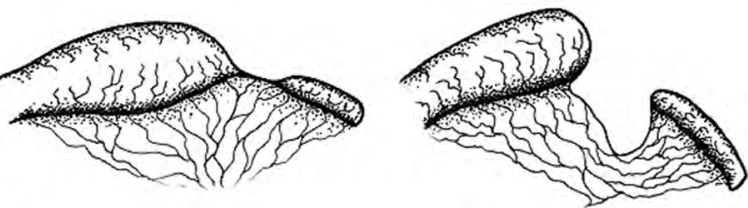

(c)

(D) Type III (a)
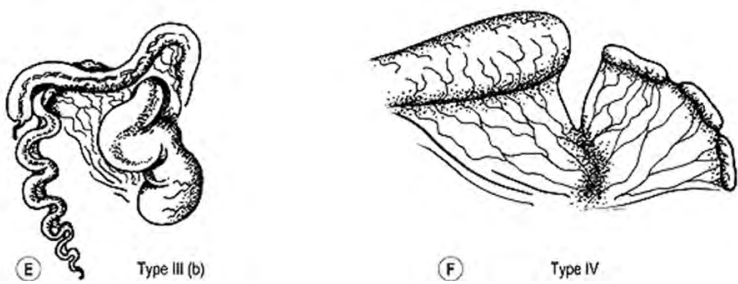

5.1.4. Tắc ruột phân su

- Phân su tồn tại dai dẳng trong ruột (hỗng tràng, hồi tràng, đại tràng) dẫn đến tắc ruột.

- Tắc ruôt phân su xuất hiện ở $15 \%$ trẻ sơ sinh mắc bênh xơ nang.

- Chỉ 5 - 10\% bệnh nhận tắc ruột phân su không có xơ nang.

- Phim chụp bụng cho thấy nhiều quai ruột giãn với thành ruột dày.

- Phim cản quang: Một số lượng lớn phân su trộn lẫn với khí được gọi là dấu hiệu "bong bóng xà phòng ".

- Phim chụp cản quang chỉ ra hình ảnh đại tràng nhỏ.

\subsubsection{Bênh Hirschprung}

- Hầu hết được chẩn đoán trong giai đoạn sơ sinh.

- Triệu chứng: Nôn dịch mật, bụng chướng và không ỉa phân su, hoặc chậm ỉa phân su sau 48 giờ tuổi.

- Chẩn đoán: Phim chụp khung đại tràng cản 
quang nhiều quai ruột giãn to, không có hơi ở trực tràng, đại tràng giãn, và nhiều mức nước hơi (tắc ruột) và khí dưới cơ hoành (viêm phúc mạc thủng ruột).

- Chụp khung đại tràng cản quang: (70-75\%) không có nhu động ở đoạn vô hạch, hình ảnh "răng cưa" , thuốc cản quang lưu giữ ở đại tràng sau 24 giờ.

- 25\% trẻ bệnh có thể không có dấu hiệu trên Xquang.

- Sinh thiết: Tiêu chuẩn vàng để chẩn đoán vô hạch toàn bộ đại tràng.

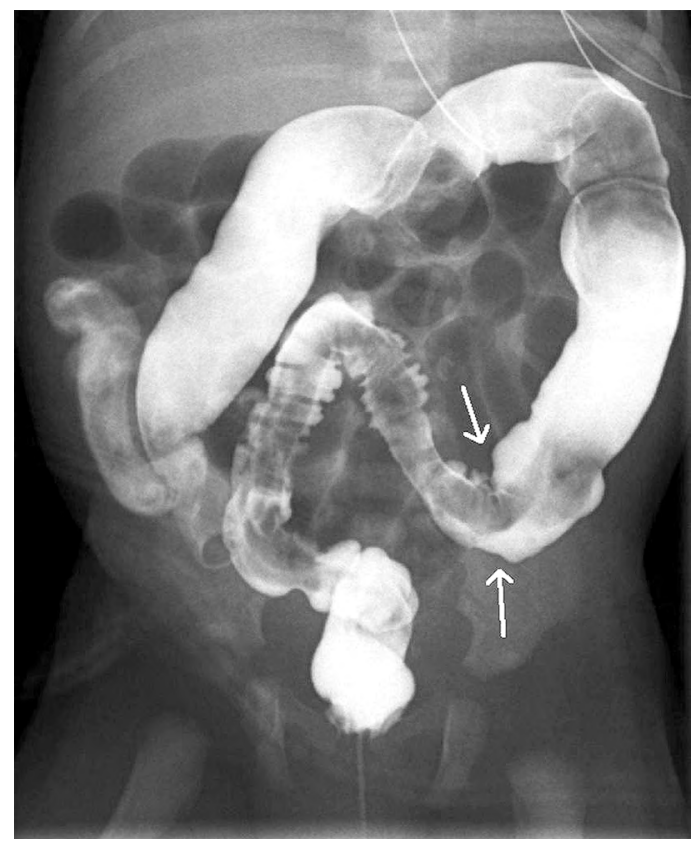

\subsubsection{Viêm ruột hoại tử}

- Viêm ruột hoại tử là bệnh tiến triển nhanh dẫn đến hoại tử ruột, nhiễm trùng và thủng ruột ở trẻ sơ sinh.

- Đẻ non và bệnh lý phổi là những yếu tố ảnh hưởng phổ biến.

- Thường xuất hiện ngày thứ 10 - 12 sau sinh với triệu chứng của dịch dạ dày, nôn dịch mật, bụng chướng và đi ngoài phân máu.

- Chậm nhịp tim, hạ nhiệt độ, ngừng thở và hạ huyết áp là những dấu hiệu của bệnh tiến triển nặng dần.

- Xuất huyết bất thường, tăng bilirubin và thiểu niệu là những dấu hiệu muộn của bệnh.

\section{NÔN KHÔNG D!̣CH MậT}

\begin{tabular}{|l|l|l|}
\hline \multicolumn{1}{|c|}{ Chăm sóc } & \multicolumn{1}{|c|}{ Bệnh nội khoa } & Ngoại khoa (Hiếm) \\
\hline Bú quá nhiều & Tiêu chảy & Hẹp đoạn trên tá tràng \\
\hline Bú mẹ không đúng cách & Viêm đường hô hấp & Hẹp môn vị \\
\hline Bú bình & Nhiễm trùng thần kinh: VMNM & Xoắn dạ dày \\
\hline Tư thế & Tăng áp lực nội sọ: Xuất huyết não & Tụy nhẫn \\
\hline Chăm sóc & Tăng sản thượng thận bẩm sinh & \\
\hline & Rối loạn thần kinh thực vật: co thắt môn vị & \\
\hline & Giảm nhu động & \\
\hline & Rối loạn nhu động: trào ngược & \\
\hline & Không dung nạp sữa & \\
\hline & NEC & \\
\hline & Viêm dạ dày do phân su/nước ối & \\
\hline
\end{tabular}




\subsection{Hẹp phì đại môn vị}

- Thường gặp ở tuần thứ 3 - 6

- Tiến triển xấu với nôn vọt và mất nước

- Kiềm chuyển hóa với giảm kali máu

- Chẩn đoán bằng siêu âm - hẹp phì đại cơ môn vị.

- Dịch và điện giải

- Phẫu thuật

- Có thể cho ăn lại sớm sau phẫu thuật.

\subsection{Không dung nạp sữa bò}

- Không dung nạp protein sữa bò - trẻ thường có dấu hiệu của dị ứng như nổi ban hoặc khò khè.

- Thiếu hụt lactase bẩm sinh trong giai đoạn sơ sinh là rất hiếm.

- Phổ biến là thiếu hụt lactase thứ phát dẫn đến viêm dạ dày ruột.

- Bà mẹ cho con bú nên loại bỏ tất cả sản phẩm sữa ra khỏi chế độ ăn của họ.

- Sữa thủy phân.

\subsection{Rối loạn nhu động}

- Trào ngược dạ dày thực quản

- Rất phổ biến ở trẻ sơ sinh

- Liên quan với trẻ sinh non và trẻ đẻ mổ

- Hầu hết không phải điều trị

- Chỉ điều trị nếu trẻ không phát triển hoặc trào ngược có liên quan đến tình trạng ngừng thở/chậm nhịp tim.

- Không điều trị

- Nằm đầu cao sau ăn

- Thức ăn đặc

- Gaviscon

- Thuốc hỗ trợ nhu động: domperidone (Motilium), erythromycin.

- Kháng $\mathrm{H} 2$ : ranitidine
- Ức chế bơm Proton: omeprazole (Nexium)

\subsection{Nhiễm khuẩn}

- Nhiễm trùng tái phát với viêm dạ dày ruột

- Thường do virus và diễn ra trong thời gian ngắn.

- Tầm quan trọng của việc phòng ngừa và kiểm soát nhiễm khuẩn trong chăm sóc trẻ.

- Nước và duy trì cân bằng điện giải.

\subsection{Do sai lầm về ăn uống và chăm sóc}

- Cho trẻ ăn quá nhiều, bú quá no, ép ăn quá ngưỡng.

- Cho trẻ bú mẹ không đúng tư thế, hoặc bú bình chưa đúng cách, làm trẻ nuốt phải nhiều khí vào dạ dày gây nôn trớ.

- Trẻ vừa ăn no đã đặt trẻ nằm ngay

- Quấn tã chăn quá chặt, băng rốn chặt

- Hướng dẫn bà mẹ tư thế bú đúng, cho trẻ bú từ từ, đủ cữ, không ép trẻ ăn quá no.

- Hướng dẫn cách cho trẻ bú bình, cách pha sữa.

- Khi trẻ đã ăn no, hướng dẫn cách bế, cách vỗ ợ hơi, cách đặt trẻ. Không bế xốc trẻ, đùa với trẻ khi trẻ vừa ăn no.

- Hướng dẫn massage quanh rốn nhẹ nhàng làm giảm co bóp dạ dày hạn chế nôn trớ.

- Massage có tác dụng kích thích dây thần kinh phế vị, tăng nhu động dạ dày, giúp hấp thu thức ăn tốt hơn, giúp trẻ tăng cân tốt hơn.

\section{KẾT LUẬN}

Nôn trớ là triệu chứng thường gặp ở trẻ sơ sinh. Nôn có thể là biểu hiện sớm của các bệnh lý bất thường. Vi vậy, khi gặp phải một trẻ sơ sinh có vấn đề nôn trớ cần phải khám lâm sàng kỹ càng và luôn phải chú ý rằng nôn dịch xanh cần nghĩ đến loại trừ các nguyên nhân ngoại khoa sớm. 